\title{
IGF-1 Deletion Affects Renal Sympathetic Nerve Activity, Left Ventricular Dysfunction, and Renal Function in DOCA-Salt Hypertensive Mice
}

\author{
Bing XIAO ${ }^{1}$, Fan LIU ${ }^{1}$, Jing-Chao LU ${ }^{1}$, Fei CHEN ${ }^{1}$, Wei-Na PEI ${ }^{1}$, Xiu-Chun YANG ${ }^{1}$ \\ ${ }^{1}$ Department of Cardiology, the Second Hospital of Hebei Medical University, Shijiazhuang, Hebei \\ Province, China
}

Received March 29, 2018

Accepted September 13, 2018

Epub Ahead of Print January 10, 2019

\section{Summary}

The objective of the paper is to determine the influence of IGF-1 deletion on renal sympathetic nerve activity (RSNA), left ventricular dysfunction, and renal function in deoxycorticosterone acetate (DOCA)-salt hypertensive mice. The DOCA-salt hypertensive mice models were constructed and the experiment was classified into WT (Wild-type mice) +sham, LID (Liverspecific IGF-1 deficient mice) + sham, WT + DOCA, and LID + DOCA groups. Enzyme-linked immunosorbent assay (ELISA) was used to detect the serum IGF-1 levels in mice. The plasma norepinephrine (NE), urine protein, urea nitrogen and creatinine, as well as RSNA were measured. Echocardiography was performed to assess left ventricular dysfunction, and HE staining to observe the pathological changes in renal tissue of mice. DOCA-salt induction time-dependently increased the systolic blood pressure (SBP) of mice, especially in DOCA-salt LID mice. Besides, the serum IGF-1 levels in WT mice were decreased after DOCA-salt induction. In addition, the plasma NE concentration and NE spillover, urinary protein, urea nitrogen, creatinine and RSNA were remarkably elevated with severe left ventricular dysfunction, but the creatinine clearance was reduced in DOCA-salt mice, and these similar changes were obvious in DOCA-salt mice with IGF- 1 deletion. Moreover, the DOCA-salt mice had tubular ectasia, glomerular fibrosis, interstitial cell infiltration, and increased arterial wall thickness, and the DOCA-salt LID mice were more serious in those aspects. Deletion of IGF-1 may lead to enhanced RSNA in DOCA-salt hypertensive mice, thereby further aggravating left ventricular dysfunction and renal damage.

\section{Key words}

IGF-1 - DOCA-salt hypertension - Renal sympathetic nerve activity • Left ventricular dysfunction • Renal impairment

\section{Corresponding author}

Xiu-Chun Yang, Department of Cardiology, the Second Hospital of Hebei Medical University, No.215 Hepingxi Road, Qiaoxi District, Shijiazhuang 050000, Hebei Province, China. E-mail: yangxc1973@126.com

\section{Introduction}

Hypertension, as a crucial risk factor for cardiovascular diseases, refers to a clinical syndrome featured by the persistent increase of blood pressure (Tapia-Castillo et al. 2014). Unfortunately, no special symptoms are shown at the early stages of hypertension, but when observed, the blood pressure has often reached the standard level for clinical hypertension (Lake-Bruse and Sigmund, 2000). To our knowledge, hypertension is a multifactorial disease, which is possibly related to patients' renal function, renal sympathetic nervous system, high-salt intake, and other factors (Fujita, 2014). Salt sensitivity has been estimated to be exhibited in approximately $51 \%$ of the world's adult population suffering from hypertension (Armando et al. 2015, Zhang et al. 2016). Thus, it is valuable to explore the unknown etiology of hypertension via an animal model, like the deoxycorticosterone acetate (DOCA)-salt model of hypertension.

Up till now, increasing attention has been 
focused on the insulin-like growth factor system (IGFs) in the development and progression of cardiovascular diseases (Heald et al. 2003). As a group of polypeptides with the structure highly homologous to insulin, IGFs includes IGF-1, IGF-2, and receptors on the cell membrane (IGF-1R and IGF-2R), as well as insulin-like growth factor-binding proteins (IGFBP) (Kota et al. 2012). As for IGF-1, it is a single-chain polypeptide consisting of 70 amino acids, mainly synthesized and secreted by liver cells, and circulating in the blood (Anderle et al. 2002). IGF-1, one of the most crucial regulators of growth, has vasodilatory effects, and causes partial reversion of hypertension-induced changes in cardiac function (Cascella et al. 2010, Tanaka et al. 2018). It can promote the proliferation of vascular smooth muscle cells (VSMCs) (Shuang et al. 2018), consequently resulting in hypertension (Perros et al. 2007). Likewise, some researchers also revealed a significantly reduced expression of IGF-1 in the myocardial tissue and serum of patients with hypertension (Fernandez-Sola et al. 2015, Zhang et al. 2011). This is inconsistent with the above mentioned results, indicating a controversial role of IGF-1 in hypertension pathogenesis. In this paper, we used the liver-specific IGF-1 deficient (LID) mice model subjected to DOCA-salt treatment, a commonly used intervention to induce hypertension (Imenshahidi et al. 2014) and we investigated the effect of IGF-1 deletion on the left ventricular dysfunction, RSNA and renal function in hypertensive mice.

\section{Materials and Methods}

\section{Ethics statement}

This study was in line with the Guide for the Care and Use of Laboratory Animals published by National Research Council (2011) and all animal experiments were carried out under the supervision of the Ethics Committee for Medical Laboratory Animals in Hebei Medical University (IACUC-Hebmu-2018056).

\section{Laboratory animal}

Male C57BL/6 WT (Wild type) mice (4 months of age) with a homozygous floxed exon 4 of the IGF-1 gene $\left(\mathrm{IGF}-1^{\text {flox/flox }}\right)$ were bought from Jackson Laboratories (Bar Harbor, ME, USA). The LID mice in this experiment were obtained by Cre/loxP recombination strategy, as described in a previous study (Tarantini et al. 2017). All mice were housed under specific pathogen- free conditions with access to standard rodent chow and water on a 12-h light-dark cycle.

DOCA-salt sensitive hypertension model construction and experimental grouping

There were 4 groups (with 20 mice in each group) in this experiment, including WT + sham, LID + sham, WT + DOCA, LID + DOCA groups. Mice in DOCA groups were anesthetized by an intraperitoneal injection of chloral hydrate $(400 \mathrm{mg} / \mathrm{kg})$. Next, the left kidney of mice was exposed from the abdominal cavity, and the left artery, vein and ureter were carefully separated with microsurgical forceps, followed by the electrocoagulation of the left kidney artery and vein. After that, the eye scissors were used to cut the ligated renal artery, vein and ureter along the distal end of the ligation thrum for left kidney resection. When postoperative bleeding stopped, the muscle and skin of mice were sutured in turn, and the mice received postoperative intraperitoneal injection of penicillin (100,000 units/day) for 3 days to prevent infection. One week later, the mice were subcutaneously injected with DOCA by $50 \mathrm{mg} / \mathrm{kg}$ (once a week for 5 consecutive weeks), and drank water containing $1 \% \mathrm{NaCl}$ and $0.2 \% \mathrm{KCl}$. By contrast, mice in sham groups only received uninephrectomy and given normal tap water for drinking. The systolic blood pressure (SBP) was determined via a non-invasive tail cuff method (Kent Scientific, Torrington, CT; model XBP 1000) once a week for 4 consecutive weeks. Before experiment, mice were acclimated for 2 weeks to the blood pressure measuring device.

\section{Detection of serum IGF-1 levels}

After the determination of SBP on the $28^{\text {th }}$ day of the experiment, blood samples were immediately collected from the submandibular vein of mice and centrifuged at $4{ }^{\circ} \mathrm{C}$ with the centrifugal force of $2500 \mathrm{~g}$ for $20 \mathrm{~min}$. The obtained serum was preserved at $-80{ }^{\circ} \mathrm{C}$ for later use. IGF-1 concentration in the serum samples was measured by the enzyme-linked immunosorbent assay (ELISA) (R\&D Systems, Minneapolis, MN, USA).

\section{Norepinephrine (NE) spillover}

The blood sample $(1 \mathrm{ml})$ was immediately obtained and preserved at $-80^{\circ} \mathrm{C}$ after the determination of SBP on the 28th day of the experiment. Solid phase extraction and high-performance liquid chromatography with electrochemical detector (HPLC-ECD) (ESA Biosciences, Inc, Chelmsford, MA, USA) were employed 
to determine the NE concentration in plasma. Levo-[ring2, 5, 6- 3H]NE (Perkin-Elmer, Boston, MA, USA, $0.13 \mu \mathrm{Ci} \cdot \mathrm{min}^{-1} \cdot \mathrm{kg}^{-1}$ ) were infused intravenously at the rate of $16 \mu \mathrm{l} / \mathrm{min}$ for $90 \mathrm{~min}$ to maintain the stable plasma concentration of $3 \mathrm{H}-\mathrm{NE}$ (King et al. 2008). NE clearance and spillover were calculated as described previously (Kandlikar and Fink 2011).

\section{Urine biochemical test}

After the determination of SBP, mice in each group were accessed to water and food for $24 \mathrm{~h}$, and then the urine samples were collected with the toluene anticorrosion (1\%). Next, $1.5 \mathrm{ml}$ of urine samples was determined for urinary protein, urea nitrogen and creatinine by using an automatic biochemical analyzer.

\section{Echocardiography examination}

After the determination of SBP on the 28th day of the experiment, five mice were randomly selected from each group for intraperitoneal anesthesia with chloral hydrate $(400 \mathrm{mg} / \mathrm{kg})$, fixed on the operation table, and a horizontal skin incision was made in the midline of the neck to separate the subcutaneous tissue. The right common carotid artery was exposed and ligated at the distal end, with a vascular clamp at the proximal end to block the bleeding. Then, the Vevo 2100 ultrasonic machine (Visual Sonics, Toronto, Canada) was utilized to measure the interventricular septal thickness in diastole (IVSd), interventricular septal thickness in systole (IVSs), left ventricular posterior wall thickness in diastole (LVPWd), left ventricular posterior wall thickness in systole (LVPWs), left ventricular anterior wall thickness in diastole (LVAWd), left ventricular anterior wall thickness in systole (LVAWs), left ventricular internal diameter in diastole (LVIDd), and left ventricular internal diameterin systole (LVIDs).

\section{Measurement of renal sympathetic nerve activity (RSNA)}

On the $28^{\text {th }}$ day of the experiment, another five mice were randomly selected from each group to expose their left kidney by cutting the skin along an extraperitoneal tunnel running from the incision to the left flank of the abdominal cavity. In the abdominal aorta area, left kidney sympathetic nerves were carefully separated with a glass needle, which was immersed in warm liquid paraffin. Meanwhile, a bipolar silver electrode was used to record RSNA beneath the renal nerve, which was amplified by a differential amplifier and recorded by Powerlab ${ }^{\circledR} 8 / 30$ to obtain the raw RSNA and the integrated RSNA. The RSNA was evaluated based on the previous study (Fardin et al. 2012).

\section{HE staining}

Further five mice were selected from each group for intraperitoneal anesthesia with $10 \%$ chloral hydrate (400 mg/kg) and cut the skin along the median line to open the abdomen and thoracic cavity. The kidney was fully exposed and taken out, rinsed with normal saline, fixed in $10 \%$ formaldehyde solution, dehydrated routinely, embedded with paraffin, and cut into $4 \mu \mathrm{m}$ thick slices. After the slices were deparaffinized, they were stained in hematoxylin for 5-10 min, immersed in $0.5 \%$ hydrochloric acid in the presence of $70 \%$ ethanol for 30-60 s, sunk in alkaline solution, washed with distilled water for $1 \mathrm{~min}$, and stained in eosin for 30-60 s. Then, slices were dehydrated with gradient alcohol, hyalinized with xylene, mounted in neutral gum, and observed under a microscope.

\section{Statistical analysis}

All statistical data were analyzed with the statistical software SPSS. The measurement data were presented by mean $\pm \mathrm{SD}$. The independent sample $t$-test was applied to compare difference between two groups, while among multiple groups compared by One-Way ANOVA. Besides, the inter-group difference was analyzed by the least significant difference (LSD) test. $P<0.05$ indicated the statistical significance.

\section{Results}

Deletion of IGF-1 gene resulted in the increased SBP in DOCA-salt hypertensive mice

According to our results, DOCA-salt treatment could time-dependently increase the SBP of mice. SBP was significantly higher in mice from WT + DOCA group and LID + DOCA group than in those from WT + sham group and LID + sham group on the $14^{\text {th }}, 21^{\text {st }}$, and $28^{\text {th }}$ day of the DOCA-salt treatment, respectively (all $P<0.05)$. Moreover, mice in the LID + DOCA group had remarkably elevated SBP, as compared with those in the $\mathrm{WT}+$ DOCA group on the $14^{\text {th }}, 21^{\text {st }}$, and $28^{\text {th }}$ day (all $P<0.05$, Fig. 1).

\section{Serum IGF-1 levels of mice in four groups}

Figure 2 shows that WT + DOCA group had lower serum IGF-1 level compared to WT + sham group $(P<0.05)$. Meanwhile, there were very low serum levels 
of IGF-1 in LID mice but no difference between the LID + sham group and the LID + DOCA group $(P>0.05)$.

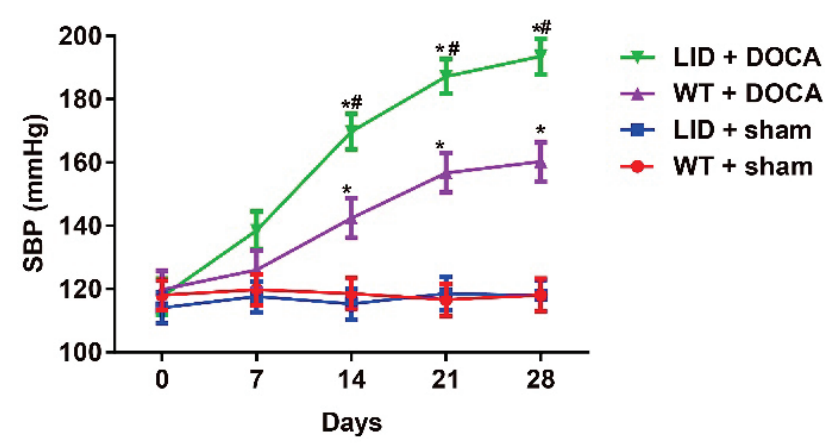

Fig. 1. Deletion of IGF-1 gene can significantly increase SBP in mice induced by DOCA-salt. *, $\mathrm{P}<0.05$ compared with sham groups; \#, $P<0.05$ compared with WT + DOCA group.

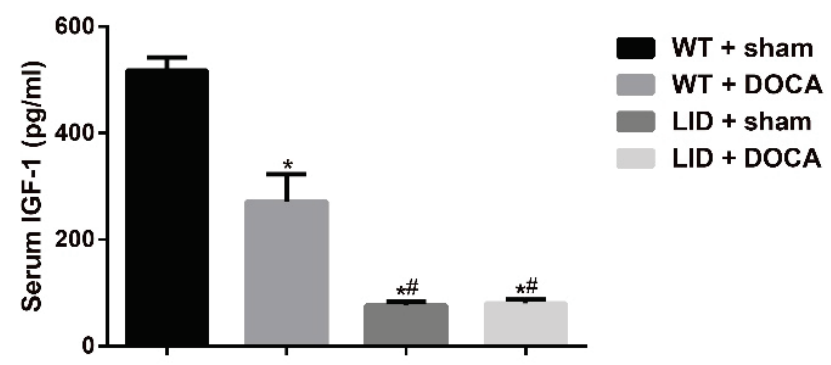

Fig. 2. Serum IGF-1 levels of mice among four groups detected by ELISA. *, $P<0.05$ compared with WT +sham group; \#, $P<0.05$ compared with WT + DOCA group.

Deletion of IGF-1 gene led to enhanced RSNA and NE Spillover in DOCA-salt hypertensive mice

RSNA was significantly enhanced in WT and LID mice after DOCA-salt treatment when compared to sham mice, but it was clearly higher in mice from LID + DOCA group than in those from $\mathrm{WT}+\mathrm{DOCA}$ group (all $P<0.05$, Fig. 3A). Besides, the plasma NE concentration and NE spillover were significantly increased in mice from the WT + DOCA group, as compared with sham mice (all $P<0.05$ ), and these elevations were even more obvious in mice from the LID + DOCA group, although no significant differences were found among sham mice (all $P>0.05$, Fig. 3B-C).

Deletion of IGF-1 gene aggravated left ventricular dysfunction in DOCA-salt hypertensive mice

The DOCA mice presented the higher left ventricular function-related indexes (IVSd, IVSs, LVPWd, LVAWd, LVAWs, LVIDd and LVIDs) than sham mice (all $P<0.05$, Table 1). These indexes were remarkably increased in mice from LID + DOCA group in comparison with those in WT + DOCA group (all $P<0.05$ ), whereas no differences were exhibited between sham groups (all $P>0.05$ ).

Deletion of IGF-1 gene aggravated renal dysfunction in DOCA-salt hypertensive mice

The DOCA mice had higher levels of urinary protein, urea nitrogen and creatinine, but lower creatinine clearance than the respective sham mice (all $P<0.05$ ). Furthermore, mice in the WT + DOCA group had significantly reduced urinary protein, urea nitrogen and creatinine, while they had elevated creatinine clearance as compared with mice in the LID + DOCA group (Fig. 4A-D). On the other hand, HE staining demonstrated that (Fig. 4E) the DOCA mice showed obvious renal histological changes (including tubular ectasia, glomerular fibrosis, interstitial cell infiltration, and increased arterial wall thickness) than sham mice. The renal dysfunction was more serious in mice from the LID + DOCA group.

A
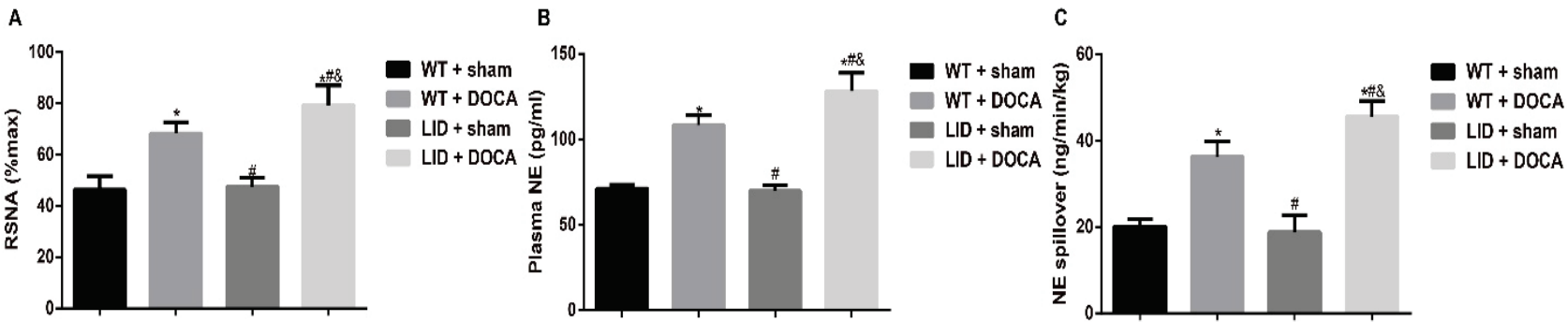

Fig. 3. Deletion of IGF-1 gene led to enhanced RSNA (A), plasma NE concentration (B) and NE Spillover (C) in DOCA-salt hypertensive mice. * $P<0.05$ compared with WT +sham group; \#, $P<0.05$ compared with WT + DOCA group; $\&, P<0.05$ compared with LID + sham group. 
Table 1. Deletion of IGF-1 gene significantly aggravated the left ventricular dysfunction in DOCA-salt hypertensive mice

\begin{tabular}{|c|c|c|c|c|}
\hline & WT + sham & WT + DOCA & LID + sham & LID + DOCA \\
\hline $\operatorname{IVSd}(\mathrm{mm})$ & $0.85 \pm 0.11$ & $1.02 \pm 0.05^{*}$ & $0.83 \pm 0.05$ & $1.29 \pm 0.09^{* \#}$ \\
\hline$I V S S(\mathrm{~mm})$ & $1.31 \pm 0.15$ & $1.50 \pm 0.04^{*}$ & $1.29 \pm 0.11$ & $1.70 \pm 0.07^{* \#}$ \\
\hline$L V P W d(\mathrm{~mm})$ & $0.75 \pm 0.06$ & $0.88 \pm 0.07^{*}$ & $0.74 \pm 0.05$ & $1.04 \pm 0.03^{* \#}$ \\
\hline$L V P W s(\mathrm{~mm})$ & $1.11 \pm 0.07$ & $1.05 \pm 0.13$ & $1.04 \pm 0.10$ & $1.08 \pm 0.05$ \\
\hline$L V A W d(\mathrm{~mm})$ & $0.78 \pm 0.05$ & $0.87 \pm 0.03^{*}$ & $0.77 \pm 0.05$ & $0.96 \pm 0.03^{* \#}$ \\
\hline$L V A W_{s}(m m)$ & $1.17 \pm 0.05$ & $1.31 \pm 0.01^{*}$ & $1.19 \pm 0.03$ & $1.45 \pm 0.09^{* \#}$ \\
\hline $\operatorname{LVIDd}(\mathrm{mm})$ & $3.47 \pm 0.11$ & $3.82 \pm 0.15^{*}$ & $3.33 \pm 0.17$ & $4.38 \pm 0.07^{* \#}$ \\
\hline $\operatorname{LVIDs}(\mathrm{mm})$ & $2.55 \pm 0.10$ & $2.95 \pm 0.25^{*}$ & $2.53 \pm 0.23$ & $3.43 \pm 0.12^{* \#}$ \\
\hline
\end{tabular}

IVSd, interventricular septal thickness in diastole; IVSs, interventricular septal thickness in systole; LVPWd, left ventricular posterior wall thickness in diastole; LVPWs, left ventricular posterior wall thickness in systole; LVAWd, left ventricular anterior wall thickness in diastole; LVAWs, left ventricular anterior wall thickness in systole; LVIDd, left ventricular internal diameter in diastole; LVIDs, left ventricular internal diameter in systole; ${ }^{*}, P<0.05$ compared with sham groups; \#, $P<0.05$ compared with WT + DOCA group.

A

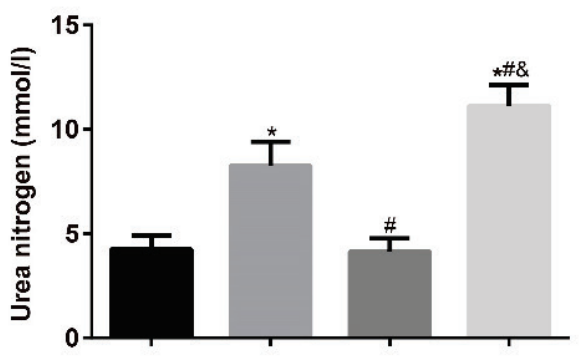

C

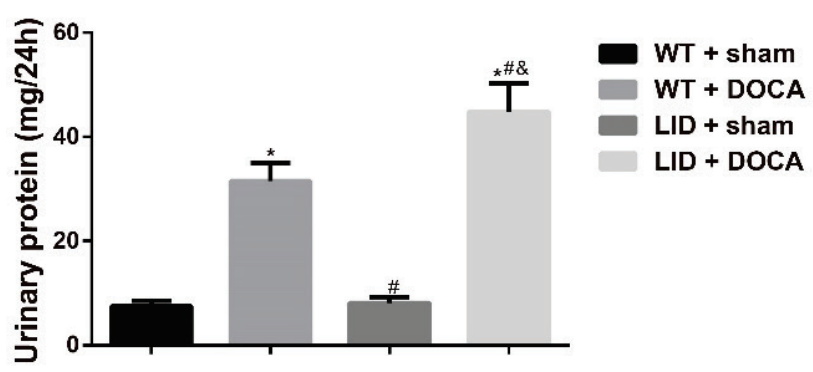

E

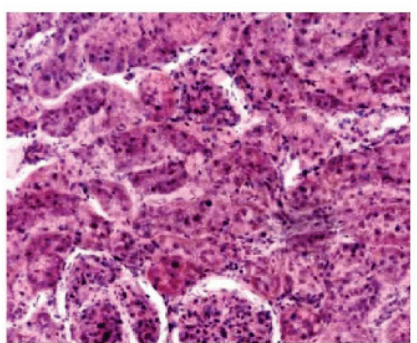

WT + sham

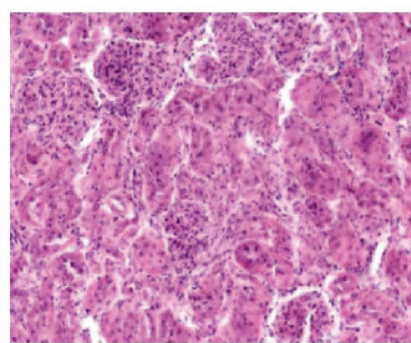

WT + DOCA

B

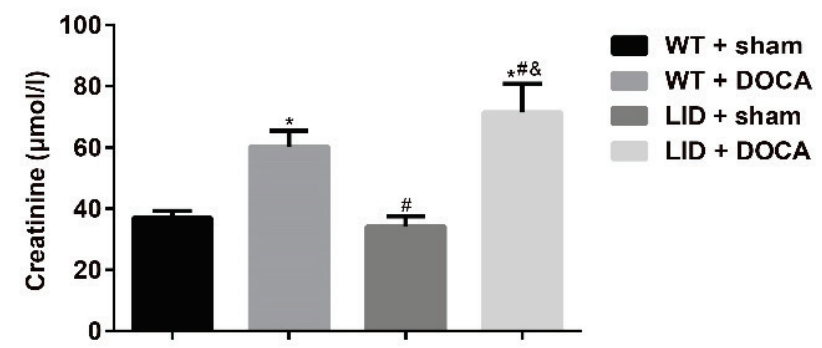

D

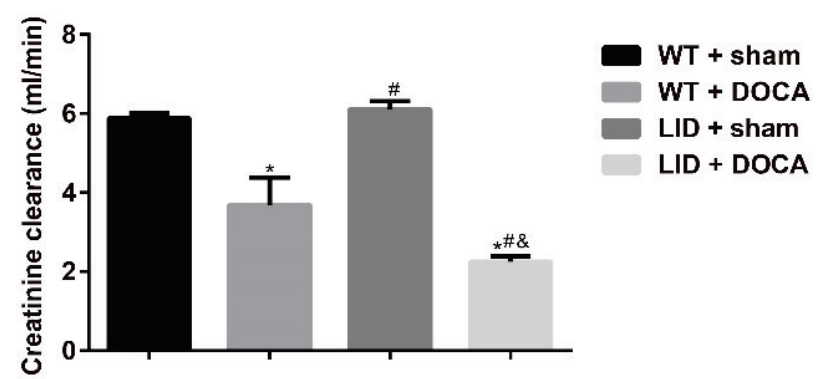

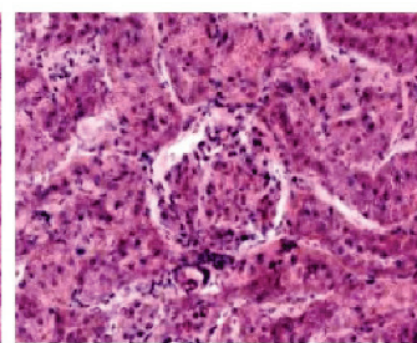

ㄴID + sham

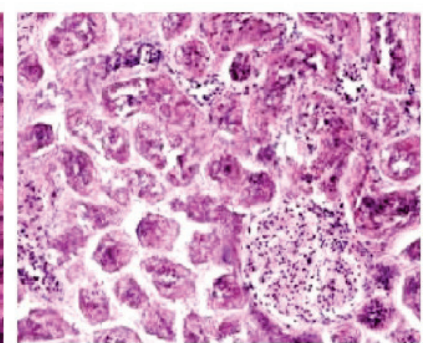

LID + DOCA

Fig. 4. Deletion of IGF-1 gene on renal dysfunction in DOCA-salt hypertensive mice. (A-D) Comparison of the levels of urine protein, urea nitrogen, creatinine and creatinine clearance of mice among each group; ${ }^{*}, P<0.05$ compared with WT + sham group; \#, $P<0.05$ compared with WT + DOCA group; \&, $P<0.05$ compared with LID + sham group; (E) The pathological changes of renal tissues in mice among each group evaluated by HE staining $(\times 10$, scale bar $=50 \mu \mathrm{m})$ 


\section{Discussion}

Salt is the main cause of elevated blood pressure in DOCA-salt hypertensive mice, because in the absence of salt, the blood pressure of mice would not increase significantly even after removing the kidney or subcutaneously given DOCA (Krishnan et al. 2016). Thus, in the current study DOCA-salt hypertension was induced in mice subjected to subcutaneous injection of DOCA after uninephrectomy and receiving $1 \% \mathrm{NaCl}$ solution to drink. As a consequence, the SBP in mice was significantly increased and renal damage (like proteinuria) was observed, which was consistent with the previous study (Jennings et al. 2012). Importantly, IGF-1 has been identified as a protective factor for cardiovascular system through a variety of ways, such as inhibiting the vascular endothelial cell injury, which was negatively linked to some cardiovascular risk factors (Yang et al. 2012), including hypertension (Vickers et al. 2001). For example, the cavernous IGF-1 bioavailability and levels were found to be dramatically reduced in patients with hypertension (Zhang et al. 2011, Zhou et al. 2016). A similar decreased serum level of IGF-1 was also observed in DOCA-salt hypertensive mice. A possible explanation is that there might be a mutation in the IGF1 gene in patients with hypertension, causing the downregulation of circulating IGF1 levels (Yang et al. 2012). Moreover, we also confirmed that the mice in LID + DOCA groups and LID + sham groups had the lower serum IGF-1 levels than those in WT + DOCA and WT + sham groups, since the LID mice had a complete deficiency of IGF-1 knocked out by the Cre/loxP homologous recombination, leading to the significant decreased serum levels of IGF-1. Besides, the reduction of IGF1 levels caused by the hypertension was not stronger than the complete deficiency of IGF-1, therefore the mice in WT + DOCA group had higher serum levels of IGF-1 than those in LID + sham group. In addition, the LID mice and WT mice are comparable owing to the same LoxP structure and genetic stability (Ealey et al. 2008). Furthermore, hypertension is the clinical syndrome featured by increased arterial blood pressure, namely, the SBP above $140 \mathrm{~mm} \mathrm{Hg}$ (Jones, 2017). However, SBP (measured in this study by the tail-cuff method) increased time-dependently in DOCA-salt hypertensive mice, SBP increase being higher in LID mice. This suggests that IGF-1 gene deletion enhanced blood pressure response to DOCA-salt treatment, possibly due to the reduced vascular bioavailability of nitric oxide (NO), eventually promoting the progression of hypertension (Yang et al. 2012). However, no variation of the SBP was found between the LID + sham group and WT + sham group in our study. In addition, pulse pressure was not correlated with serum IGF-1 levels in healthy women as reported by JH Kim et al. (2006), indicating the $I G F-1$ deletion may not affect SBP of the healthy mice or individuals.

Over-enhancement of sympathetic nerve activity (SNA) is accepted as an important characteristic of hypertension, thus the reduction of increased SNA constitutes one of the major targets for the prevention and treatment of hypertension (de Almeida Chaves Rodrigues et al. 2013). As we know, the renal sympathetic nerve has higher sympathetic nerve activity (SNA) than any other nerves, which could better reflect the cardiovascular SNA level and the central SNA level (Baum, 2018). Indeed, we observed the apparent increase of RSNA in mice from the DOCA groups (WT + DOCA group and LID + DOCA group) as compared with the sham groups (WT + sham group and LID + sham group), and the increase was higher in mice from LID + DOCA group than those from WT + DOCA group. Consistently, IGF-1 has been found to reduce the lumbar sympathetic nerve activity (LSNA) and RSNA (Duanmu et al. 1997), which was related to the activity of GH/IGF-1 axis (Sverrisdottir et al. 2010). On the other hand, the long-term stimulation has been reported to lead to the increase of NE spillover in peripheral blood, which faithfully reflects the state of RSNA (Noshiro et al. 1991). Thus, the plasma NE concentration and NE spillover detected in this experiment were clearly higher in LID mice with DOCA-salt treatment, However, the RSNA, plasma NE concentration and NE spillover in the LID + sham are lower than in the WT + DOCA, which indirectly indicated that IGF-1 gene deletion may cause the enhancement of RSNA and NE spillover in the progression of hypertension, but having no effects in sham mice. Recent study reported that an increase in SNA may be responsible for left ventricular dysfunction (Guizar-Mendoza et al. 2006). In accordance, the leftventricular function related indicators, such as IVSd, IVSs, LVPWd, LVAWd, LVAWs, LVIDd, and LVIDs were elevated in DOCA-salt hypertensive LID mice. A previous study also discovered the reduction of serum IGF-1 levels also in patients with left ventricular dysfunction (Abe et al. 2006). Notably, Enoki et al. reported that mesenchymal stem cells loaded with IGF-1 can effectively improve the left ventricular function in 
rats undergoing myocardial infarction (Enoki et al. 2010), indirectly indicating that IGF-1 gene deletion can aggravate the condition of left ventricular dysfunction in hypertensive patients or animals.

Finally, the kidney, as one of the major target organs in hypertensive disease, is responsible for removing waste products and excess water (Mule et al. 2017). The pathological renal change in hypertension mainly include tubular ectasia, glomerular fibrosis, interstitial cell infiltration, and increased arterial wall thickness (Wang et al. 2013). Similar results were disclosed by HE staining in the kidneys of our WT + DOCA mice. It is worth mentioning that the LID mice had more severe renal impairment than WT mice among the mice treated by DOCA-salt. It was demonstrated that IGF-1 was dramatically decreased in patients with acute renal failure (ARF) and reflux nephropathy (RN) (Kornhauser et al. 2002). There is a possibility that the poor expression of IGF-1 may promote the deposition of interstitial collagen and the apoptosis of renal tubular cells to deteriorate the renal function (Chertin et al. 2004). As previous studies demonstrated, urinary protein and creatinine levels of hypertensive patients were significantly higher than the healthy controls, which could diagnose renal damage in patients with hypertension (Wang et al. 2015, Zhu et al. 2015). In our experiment, we also found that as compared with sham groups, the DOCA-salt hypertensive mice had the apparent elevation in urinary protein, urea nitrogen and creatinine, and the reduction of creatinine clearance, which changed more obvious in mice from LID + DOCA group. $\mathrm{H}$ Yasuda and his group demonstrated that injection of recombinant human IGF-1 (rhIGF-1) reduced serum creatinine and urea nitrogen levels in cisplatin (CDDP) group but not in CDDP-untreated rats (Yasuda et al. 2004). All mention above further suggested that IGF-1 deletion may cause a more severe renal damage in DOCA-salt hypertensive mice.

In summary, we found that deletion of IGF-1 gene may promote the increase in RSNA and up-regulate the levels of plasma NE concentration and NE spillover, eventually aggravating the left ventricular dysfunction and renal damage in DOCA-salt hypertensive mice.

\section{Conflict of Interest}

There is no conflict of interest.

\section{Acknowledgements}

The authors would also like to thank all the reviewers for assisting in this study.

\section{References}

ABE N, MATSUNAGA T, KAMEDA K, TOMITA H, FUJIWARA T, ISHIZAKA H, HANADA H, FUKUI K, FUKUDA I, OSANAI T, OKUMURA K: Increased level of pericardial insulin-like growth factor-1 in patients with left ventricular dysfunction and advanced heart failure. J Am Coll Cardiol 48: 1387-1395, 2006.

ANDERLE P, LANGGUTH P, RUBAS W, MERKLE HP: In vitro assessment of intestinal IGF-I stability. J Pharm Sci 91: 290-300, 2002.

ARMANDO I, VILLAR VA, JOSE PA: Genomics and Pharmacogenomics of Salt-sensitive Hypertension. Curr Hypertens Rev 11: 49-56, 2015.

BAUM M: Role of renal sympathetic nerve activity in prenatal programming of hypertension. Pediatr Nephrol 33: 409-419, 2018.

CASCELLA T, RADHAKRISHNAN Y, MAILE LA, BUSBY WH, JR., GOLLAHON K, COLAO A, CLEMMONS DR: Aldosterone enhances IGF-I-mediated signaling and biological function in vascular smooth muscle cells. Endocrinology 151: 5851-5864, 2010.

CHERTIN B, FARKAS A, PURI P: Insulin-like growth factor-1 expression in reflux nephropathy. Pediatr Surg Int 20: 283-289, 2004.

DE ALMEIDA CHAVES RODRIGUES AF, DE LIMA IL, BERGAMASCHI CT, CAMPOS RR, HIRATA AE, SCHOORLEMMER GH, GOMES GN: Increased renal sympathetic nerve activity leads to hypertension and renal dysfunction in offspring from diabetic mothers. Am J Physiol Renal Physiol 304: F189-F197, 2013.

DUANMU Z, LAPANOWSKI K, DUNBAR JC: Insulin-like growth factor-I decreases sympathetic nerve activity: the effect is modulated by glycemic status. Proc Soc Exp Biol Med 216: 93-97, 1997.

EALEY KN, XUAN W, LU S, ARCHER MC. Colon carcinogenesis in liver-specific IGF-I-deficient (LID) mice. Int J Cancer 122: 472-476, 2008. 
ENOKI C, OTANI H, SATO D, OKADA T, HATTORI R, IMAMURA H. Enhanced mesenchymal cell engraftment by IGF-1 improves left ventricular function in rats undergoing myocardial infarction. Int J Cardiol 138: 9-18, 2010.

FARDIN NM, OYAMA LM, CAMPOS RR. Changes in baroreflex control of renal sympathetic nerve activity in highfat-fed rats as a predictor of hypertension. Obesity (Silver Spring) 20: 1591-1597, 2012.

FERNANDEZ-SOLA J, BORRISSER-PAIRO F, ANTUNEZ E, TOBIAS E. Myostatin and insulin-like growth factor-1 in hypertensive heart disease: a prospective study in human heart donors. J Hypertens 33: 851-858; discussion 859, 2015.

FUJITA T. Mechanism of salt-sensitive hypertension: focus on adrenal and sympathetic nervous systems. $J$ Am Soc Nephrol 25: 1148-1155, 2014.

GUIZAR-MENDOZA JM, AMADOR-LICONA N, LOZADA EE, RODRIGUEZ L, GUTIERREZ-NAVARRO M, DUBEY-ORTEGA LA, TREJO-BELLIDO J, ENCARNACION JDE J, RUIZ-JARAMILLO MDE L: Left ventricular mass and heart sympathetic activity after renal transplantation in children and young adults. Pediatr Nephrol 21: 1413-1418, 2006.

HEALD AH, ANDERSON SG, IVISON F, LAING I, GIBSON JM, CRUICKSHANK K: C-reactive protein and the insulin-like growth factor (IGF)-system in relation to risk of cardiovascular disease in different ethnic groups. Atherosclerosis 170: 79-86, 2003.

IMENSHAHIDI M, RAZAVI BM, FAAL A, GHOLAMPOOR A, MOUSAVI SM, HOSSEINZADEH H: Effects of chronic crocin treatment on desoxycorticosterone acetate (doca)-salt hypertensive rats. Iran J Basic Med Sci 17: 9-13, 2014.

JENNINGS BL, ESTES AM, ANDERSON LJ, FANG XR, YAGHINI FA, FAN Z, GONZALEZ FJ, CAMPBELL WB, MALIK KU: Cytochrome P450 1B1 gene disruption minimizes deoxycorticosterone acetate-salt-induced hypertension and associated cardiac dysfunction and renal damage in mice. Hypertension 60: 1510-1516, 2012.

JONES DW: Optimal Treated Blood Pressure for Patients With Isolated Systolic Hypertension. Hypertension 69: 200-201, 2017.

KANDLIKAR SS, FINK GD: Mild DOCA-salt hypertension: sympathetic system and role of renal nerves. Am J Physiol Heart Circ Physiol 300: H1781-1787, 2011.

KIM JH, HWANG EJ, KIM SH, LEE HR, LEE DC: The Relation of Pulse Pressure to Insulin- like Growth Factor (IGF)-1. Korean J Fam Med 27: 201-207, 2006.

KING AJ, NOVOTNY M, SWAIN GM, FINK GD: Whole body norepinephrine kinetics in ANG II-salt hypertension in the rat. Am J Physiol Regul Integr Comp Physiol 294: R1262-1267, 2008.

KORNHAUSER C, DUBEY LA, GARAY ME, PEREZ-LUQUE EL, MALACARA JM, VARGAS-ORIGEL A: Serum and urinary insulin-like growth factor-1 and tumor necrosis factor in neonates with and without acute renal failure. Pediatr Nephrol 17: 332-336, 2002.

KOTA SK, JAMMULA S, GAYATRI K, KOTA SK, TRIPATHY PR, MODI KD: IGF-1 and IGFBP 3 in Growth Hormone Deficiency Role of Insulin Like Growth Factor-1 (IGF-1) and IGF Binding Protein 3 in the Diagnosis of Growth Hormone Deficiency: Changing Paradigm. J Nepal Paediatr Soc 32: 154-162, 2012.

KRISHNAN SM, DOWLING JK, LING YH, DIEP H, CHAN CT, FERENS D, KETT MM, PINAR A, SAMUEL CS, VINH A, ARUMUGAM TV, HEWITSON TD, KEMP-HARPER BK, ROBERTSON AA, COOPER MA, LATZ E, MANSELL A, SOBEY CG, DRUMMOND GR: Inflammasome activity is essential for one kidney/deoxycorticosterone acetate/salt-induced hypertension in mice. Br J Pharmacol 173: 752-765, 2016.

LAKE-BRUSE KD, SIGMUND CD: Transgenic and knockout mice to study the renin-angiotensin system and other interacting vasoactive pathways. Curr Hypertens Rep 2: 211-216, 2000.

MUle G, CASTIGLiA A, CUSUMANO C, SCADUTO E, GERACI G, ALTIERI D, Di NATALE E, CACCIATORE O, CERASOlA G, COTTONE S: Subclinical Kidney Damage in Hypertensive Patients: A Renal Window Opened on the Cardiovascular System. Focus on Microalbuminuria. Adv Exp Med Biol 956: 279-306, 2017.

NATIONAL RESEARCH COUNCIL: Guide for the Care and Use of Laboratory Animals: Eighth Edition. Washington, DC, The National Academies Press, 2011.

NOSHIRO T, SAIGUSA T, WAY D, DORWARD PK, MCGRATH BP: Norepinephrine spillover faithfully reflects renal sympathetic nerve activity in conscious rabbits. Am J Physiol 261: F44-F50, 1991. 
PERROS F, DORFMULLER P, SOUZA R, DURAND-GASSELIN I, GODOT V, CAPEL F, ADNOT S, EDDAHIBI S, MAZMANIAN M, FADEL E, HERVE P, SIMONNEAU G, EMILIE D, HUMBERT M: Fractalkineinduced smooth muscle cell proliferation in pulmonary hypertension. Eur Respir J 29: 937-943, 2007.

SHUANG T, FU M, YANG G, WU L, WANG R: The interaction of IGF-1/IGF-1R and hydrogen sulfide on the proliferation of mouse primary vascular smooth muscle cells. Biochem Pharmacol 149: 143-152, 2018.

SVERRISDOTTIR YB, JANSSON LM, HAGG U, GAN LM: Muscle sympathetic nerve activity is related to a surrogate marker of endothelial function in healthy individuals. PLoS One 5: e9257, 2010.

TANAKA $\mathrm{H}$, OISHI G, NAKANO Y, MIZUTA H, NAGANO Y, HIRAMATSU N, ANDO H, SHIMIZU M: Production of recombinant salmon insulin-like growth factor binding protein-1 subtypes. Gen Comp Endocrinol 257: 184-191, 2018.

TAPIA-CASTILLO A, CARVAJAL CA, CAMPINO C, VECCHIOLA A, ALLENDE F, SOLARI S, GARCIA L, LAVANDEROS S, VALDIVIA C, FUENTES C, LAGOS CF, MARTINEZ-AGUAYO A, BAUDRAND R, AGLONY M, GARCIA H, FARDELLA CE: Polymorphisms in the RAC1 gene are associated with hypertension risk factors in a Chilean pediatric population. Am J Hypertens 27: 299-307, 2014.

TARANTINI S, VALCARCEL-ARES NM, YABLUCHANSKIY A, SPRINGO Z, FULOP GA, ASHPOLE N, GAUTAM T, GILES CB, WREN JD, SONNTAG WE, CSISZAR A, UNGVARI Z: Insulin-like growth factor 1 deficiency exacerbates hypertension-induced cerebral microhemorrhages in mice, mimicking the aging phenotype. Aging Cell 16: 469-479, 2017.

VICKERS MH, IKENASIO BA, BREIER BH: IGF-I treatment reduces hyperphagia, obesity, and hypertension in metabolic disorders induced by fetal programming. Endocrinology 142: 3964-3973, 2001.

WANG QZ, GAO HQ, LIANG Y, ZHANG J, WANG J, QIU J: Cofilin1 is involved in hypertension-induced renal damage via the regulation of NF-kappaB in renal tubular epithelial cells. $J$ Transl Med 13: 323, 2015.

WANG XC, LIU CH, CHEN YJ, WU Y, YANG LS, LIU HM, LIAO HL. Clinical and pathological analysis of the kidney in patients with hypertensive nephropathy. Exp Ther Med 6: 1243-1246, 2013.

YANG HC, LIANG YJ, CHEN JW, CHIANG KM, CHUNG CM, HO HY, TING CT, LIN TH, SHEU SH, TSAI WC, CHEN JH, LEU HB, YIN WH, CHIU TY, CHERN CL, LIN SJ, TOMLINSON B, GUO Y, SHAM PC, CHERNY SS, LAM TH, THOMAS GN, PAN WH: Identification of IGF1, SLC4A4, WWOX, and SFMBT1 as hypertension susceptibility genes in Han Chinese with a genome-wide gene-based association study. PLoS One 7: e32907, 2012.

YASUDA H, KATO A, MIYAJI T, HUA Z, TOGAWA A, HISHIDA A: Insulin-like growth factor-I increases p21 expression and attenuates cisplatin-induced acute renal injury in rats. Clin Exp Nephrol 8: 27-35, 2004.

ZHANG L, CURHAN GC, FORMAN JP: Plasma insulin-like growth factor-1 level and risk of incident hypertension in nondiabetic women. J Hypertens 29: 229-235, 2011.

ZHANG Y, SHI Z, LIANG H, HU F, DENG M, YAN Z, LIU S, YUE W, SHEN Y, JI Y: Prevalence of hypertension in Chinese population aged over 40 and subgroup of survival stroke patients. Biomed Res-India 27: 917-922, 2016.

ZHOU ZY, CHENG SP, HUANG H, SUN YL, XIAO S, LIU RH, MAO FJ, ZHONG GJ, HUANG JB, PAN H: Decrease of the insulin-like growth factor-1 bioavailability in spontaneously hypertensive rats with erectile dysfunction. Andrologia 48: 824-828, 2016.

ZHU J, KE W, HE H: Diagnostic value of urinary protein and creatinine in combination with renal ultrasound examination in early renal damage of patients with hypertension. Pak J Med Sci 31: 899-902, 2015. 